\title{
Cephalopods and mesoscale oceanography at the Antarctic Polar Front: satellite tracked predators locate pelagic trophic interactions
}

\author{
P. G. Rodhouse*, P. A. Prince, P. N. Trathan, E. M. C. Hatfield, J. L. Watkins, \\ D. G. Bone, E. J. Murphy, M. G. White \\ British Antarctic Survey, Natural Environment Research Council, High Cross, Madingley Road, Cambridge CB3 0ET, \\ United Kingdom
}

\begin{abstract}
Predator data and exploratory fishing in the Scotia Sea have revealed the presence of cephalopod stocks in the Antarctic Polar Frontal Zone (PFZ). This is a vast, remote region where large epipelagic cephalopods aggregate into highly mobile schools making them difficult to locate and sample. We used satellite tagged predators and shipboard acoustics for coarse and fine scale location of cephalopod concentrations, and sampled them with commercial and scientific nets to determine the relationship between cephalopod distribution and mesoscale oceanographic features at the PFZ. Satellite tags were attached to 9 grey-headed albatrosses Diomedea chrysostoma, breeding at Bird Island, South Georgia, to monitor foraging at sea in January-March 1994. A foraging area at the PFZ, north of South Georgia, was located, an acoustic survey undertaken and a fixed station established where acoustic targets were found. A net survey was carried out with a commercial pelagic trawl, a rectangular midwater trawl $25 \mathrm{~m}^{2}$ (RMT25), a horizontal multiple plankton sampler and a neuston net. Acoustic layers were targeted and the RMT25 sampled $200 \mathrm{~m}$ layers to $1000 \mathrm{~m}$ in daylight and darkness. Cephalopods were simultaneously recovered from food samples fed to $D$. chrysostoma chicks at Bird Island. Two CTD transects, approximately normal to the major current flow, were undertaken across the PFZ and remote-sensed sea-surface temperature images from NOAA polar orbiting satellites were obtained aboard ship. The pelagic trawl sampled a cephalopod community that closely resembled that exploited by $D$. chrysostoma. The largest and most conspicuous species was the ommastrephid squid Martialia hyadesi which is the most important cephalopod prey species. Net-sampled M. hyadesi had been feeding on crustaceans and mesopelagic fish. The cephalopod community was sampled in a feature, interpreted as a warm core ring, in an area characterised by mesoscale features associated with the bathymetry of the northern end of the Northeast Georgia Rise and near a gap in the Falkland Ridge. The association of these mesoscale features with the bathymetry suggests that they may be predictable foraging locations for the cephalopods and their predators.
\end{abstract}

KEY WORDS: Martialia hyadesi A Acoustic targets - Warm core ring · Grey-headed albatross

\section{INTRODUCTION}

The Antarctic Polar Frontal Zone (PFZ) is a complex, circumpolar transition region between the Antarctic and sub-Antarctic surface waters characterised by the presence of eddies and meanders (Gordon et al. 1977). Recent research has revealed that the PFZ supports an

·E-mail: p.rodhouse@bas.ac.uk important, but little known, trophic system. During the 'Discovery' expeditions it was found that the diet of several vertebrate predators, especially southern elephant seals Mirounga leonina, included large numbers of cephalopods (Harrison-Matthews 1929). At that time the krill/baleen whale trophic system in the Antarctic was of primary interest and krill Euphausia superba was amenable to the research methods of the day so this species dominated ecological research in the Southern Ocean for several decades. 
Examining the cephalopod prey of vertebrate predators breeding at South Georgia, Clarke \& Prince (1981) found the diet of some species, notably grey-headed and black-browed albatrosses Diomedea chrysostoma and $D$. melanophrys, to be dominated by an ommastrephid squid which was later identified as Martialia hyadesi (Rodhouse \& Yeatman 1990). Further research indicated that $M$. hyadesi is the major squid prey of $D$. chrysostoma and D. melanophrys (Rodhouse et al. 1990, Rodhouse \& Prince 1993), that it is one of the most important species in the diet of Mirounga leonina (Rodhouse et al. 1992a) and is present in the diet of the wandering albatross $D$. exulans (Rodhouse et al. 1987). Japanese exploratory fishing at the PFZ subsequently caught commercial quantities of $M$. hyadesi to the west of Shag Rocks (Rodhouse 1991).

Although it is not possible to assess the size of the Scotia Sea stock, annual consumption of Martialia hyadesi by preadors is estimated to be $>326000 \mathrm{t}$ (Rodhouse et al. 1993). Stomach contents of the specimens caught by the Japanese jiggers showed that they had been feeding on mesopelagic fish, especially the myctophid Kreffichthys anderssoni (Rodhouse et al. 1992c). Their diet is dominated in turn by copepods (Gerasimova 1990) so this large myctophid/cephalopod/ higher predator trophic system may be partially or fully independent of the Euphausia superba system. Evidence is emerging elsewhere in the Southern Ocean of apparently large myctophid-based trophic systems at the PFZ (Adams \& Klages 1987, Hindell 1988, Cherel \& Ridoux 1992). During the 1980s a commercial fishery developed for myctophids (Filin et al. 1990, Sabourenkov 1990) and, until former Soviet Union vessels largely withdrew from the Antarctic, catches dominated the total fin-fish catch in the Commission for the Conservation of Antarctic Marine Living Resources (CCAMLR) area. Remotely sensed Coastal Zone Colour Scanner images of the Southern Ocean reveal high concentrations of plant pigments in some sectors of the PFZ, notably in the north Scotia Sea area, highlighting the presence of algal blooms and indicating elevated levels of primary production. (Comiso et al. 1993).

The PFZ is a vast, remote oceanic region and many of the epipelagic cephalopods are highly mobile so until recently there were insurmountable difficulties for scientific sampling. The acquisition of the British Antarctic Survey (BAS) research ship, RRS 'James Clark Ross' in 1990, with facilities for handling commercial size trawls, coincided with the BAS 'Higher Predator Studies Group' research on foraging, distribution and activity of albatross species at South Georgia using satellite tagging (Prince et al. 1992) and the installation of a satellite receiving station at Rothera Station, Adelaide Island (off the Antarctic
Peninsula) which provides synoptic sea surface temperatures (SSTs) from advanced very high resolution radiometer (AVHRR) data for the region. Together these provided the first opportunity to locate and sample concentrations of macro-nekton and interpret ecological processes at the PFZ. Here we describe the results of an interdisciplinary research cruise in January/February 1994 to examine pelagic ecology and predator/prey relations in the north Scotia Sea. Satellite-tagged cephalopod predators, Diomedea melanophrys and especially $D$. chrysostoma, were tracked in the period before and during the cruise and an area of foraging activity identified in the PFZ to the north of South Georgia. The ship went to this region, carried out an acoustic search, identified an area of acoustic targets in the water column and undertook a series of net surveys. Synoptic SST images were collected concurrently with a high resolution CTD (conductivity/temperature/depth) survey of the area immediately following the biological sampling programme.

We were thus able to establish the relationship between the distribution of the cephalopod community, the satellite tagged predators and associated mesoscale oceanographic features at the PFZ. Although much information has been gathered in recent years on primary production and plankton processes at fronts (Le Fevre 1986), there are few data on trophic interactions, especially among the large pelagic fish and cephalopods (Olson et al. 1994). Cephalopods are currently the third most valuable species group in the world marine harvest after shrimp and tuna (FAO 1992). There are large stocks of cephalopods in the Southern Ocean that straddle the CCAMLR area and these are key species in an ecosystem supporting large numbers of higher predators breeding at South Georgia and other peri-Antarctic Islands. Knowledge of the ecology of these stocks is essential for the effective management of this ecosystem.

Several acronyms are used in this paper They are defined where they first appear and for convenience are listed here: AAZ: Antarctic Zone; ARIES: Antarctic Reception of Imagery for Environmental Studies; AVHRR advanced very high resolution radiometer; BAS: British Antarctic Survey; CCAMLR: Commission for the Conservation of Antarctic Marine Living Resources; CTD: conductivity/temperature/depth; GIS: geographic information system; H-AMPS: horizontalAntarctic multiple plankton sampler; LRL: lower rostral length; NOAA: National Oceanic and Atmospheric Administration; ML: mantle length; PFZ: Polar Frontal Zone; PTT: platform terminal transmitter; RMT25: rectangular midwater trawl $25 \mathrm{~m}^{2}$; SAZ: Sub-Antarctic Zone; SST: sea surface temperature; XBT: expendable bathythermograph. 


\section{MATERIALS AND METHODS}

Satellite tagging and food sampling predators. In 1993 and 1994 Diomedea chrysostoma and D. melanophrys from the breeding colonies at Bird Island, off the northwest end of South Georgia, were tagged with Toyocom 2038 microwave platform terminal transmitters (PTTs) weighing between 65 and $75 \mathrm{~g}$ PTTs were attached using the method described by Prince et al. (1992). In 1993, from late January to early March, a total of $9 \mathrm{D}$. chrysostoma and $11 \mathrm{D}$. melanophrys albatross tracks were obtained from adults foraging at sea. For D chrysostoma 1307 locations were obtained from 63 foraging trips and for D. melanophrys 2071 position fixes were obtained from 67 foraging trips. Fourteen meals delivered to $D$. chrysostoma and 12 to $D$. melanophrys chicks by adults bearing PTTs were either observed directly while the chick was being fed or collected from the adult using the method described by Prince (1980). Cephalopods in the samples were identified by comparison of lower beaks, gladii and soft parts with samples caught by nets and jigs in the Scotia Sea (Rodhouse 1989, 1990, Rodhouse \& Yeatman 1990) and by reference to Clarke (1986). Lower rostral lengths (LRL) of beaks were measured to $0.1 \mathrm{~mm}$ with Vernier calipers and allometric equations given by Clarke (1986), Rodhouse \& Yeatman (1990) and Rodhouse et al. (1992c) used to estimate mantle length (ML). Satellite position fixes during the foraging trips indicated the tracks taken by the adults and the approximate area where the prey was obtained.

In 1994 five PPTs were deployed on Diomedea chrysostoma in January, during the 4 wk preceeding the sampling programme in February, in order to locate an area where foraging was concentrated and to identify an appropriate survey site. $D$. chrysostoma only were used for this purpose as their diet contains a higher proportion of cephalopods (Prince 1980) of which Martialia hyadesi contributes about $90 \%$ of the biomass (Rodhouse et al. 1990). A total of 435 position fixes were recorded, from 17 foraging trips, of which 8 were completed by the start of the sampling programme.

Concurrent with the 1994 net sampling programme, food samples were collected from a total of 37 Diomedea chrysostoma and $38 \mathrm{D}$. melanophrys returning to the colonies at Bird Island. Samples were taken at approximately weekly intervals starting on 28 January with up to 10 samples from each species collected on each day. Methods of collection and analysis of cephalopod material were as for 1993.

PTT data handling. PTT data from the tagged Diomodea chrrsostoma wore relayed to Toulouse. France, via the Argos satellite system, sent daily to BAS headquarters in Cambridge and transmitted to the RRS 'James Clark Ross' On the ship, the PTT posi- tional information was loaded into PC Arc/Info (ESRI), a geographic information system (GIS). The delay between a position fix and the data being processed on board ship was 4 to $24 \mathrm{~h}$. Plots of individual predator foraging trips were generated by the GIS, as well as a compilation plot of all trips made to the PFZ. During the $24 \mathrm{~h}$ prior to the start of the acoustics and net sampling programme the positions of $3 \mathrm{D}$. chrysostoma foraging at the PFZ were plotted at $4 \mathrm{~h}$ intervals. Following the acoustic transects a fixed station was established among these position fixes, at $49^{\circ} 48^{\prime} \mathrm{S}$, $37^{\circ} 28^{\prime} \mathrm{W}$.

Acoustics. Equipment: Acoustic data were collected with a Simrad EK500 echo-sounder and integrator operating at frequencies of 38 and $120 \mathrm{kHz}$ through hull-mounted transducers. Calibration of the echosounder system was carried out at Leith Harbour, South Georgia, on 7 January and 17 February 1994. Calibration procedures followed those of Foote et al. (1987) and Simrad (1992) whereby a target sphere of known backscattering cross-section was suspended below each transducer in turn.

Integrated data were collected during transects and net hauls from a depth of $10 \mathrm{~m}$ below the transducer to a depth of either 250 or $850 \mathrm{~m}$ below the transducer. All integrated data were logged to PC using a custom programme written in Labwindows. Continuous records of the ping-by-ping records were printed onto 2 paper charts; the first recorded 38 and $120 \mathrm{kHz}$ data from 10 to $250 \mathrm{~m}$, the second recorded $38 \mathrm{kHz}$ between 10 and $1000 \mathrm{~m}$. Echo-integrator summary tables were printed on the first paper chart at 2.5 min intervals.

Survey design: A series of zig-zag acoustic transects, coupled with surface oceanographic measurements and predator observations, were made along the frontal zone through areas where satellite-tagged Diomedea chrysostoma were foraging (Fig. 1)

Data processing: Integrated data were processed and viewed using custom modules of the Application Visualization System (Socha et al. 1996) and spurious data points definitely attributable to non-biological targets removed. The data were compensated for background noise using the technique described in detail in Watkins et al. (1996), loaded into an Oracle data base and merged with latitude and longitude for the beginning of each integration period.

Net sampling. Pelagic trawl: Larger cephalopods were sampled with an Ymuiden Stores (Netherlands) 2800 pelagic trawl (head rope: $93.2 \mathrm{~m}$; side rope: $85.5 \mathrm{~m}$; foot rope: $105 \mathrm{~m}$ ). Two double oblique hauls of $2 \mathrm{~h}$ duration each were made through the fixed station (Fig. 2), one during daylight to $1000 \mathrm{~m}$ and the other during darkness (defined by local sunrise and sunset) to $300 \mathrm{~m}$. A further $2 \mathrm{~h}$ haul targeting acoustic marks was made to a depth of ca $100 \mathrm{~m}$ in darkness. 


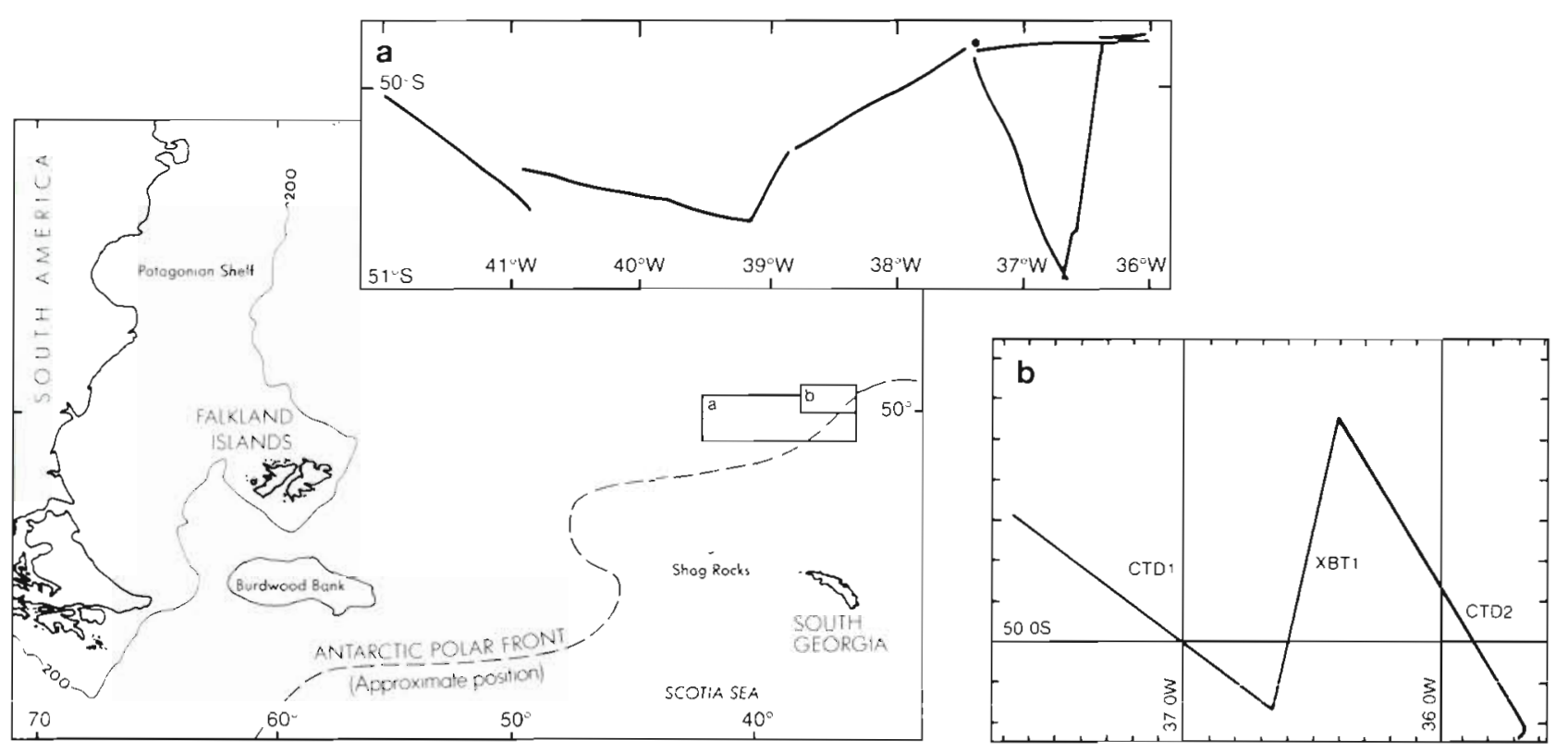

Fig. 1. Map of southwest Atlantic showing South Georgia and approximate position of Antarctic Polar Front. Inset a: acoustic transects at the Polar Frontal Zone in relation to the position of the fixed station of the sampling programme; inset b: CTD and XBT transects

Rectangular midwater trawl $25 \mathrm{~m}^{2}$ (RMT25): Smaller cephalopods were sampled with an opening/closing rectangular midwater trawl with a design aperture of $25 \mathrm{~m}^{2}$ (RMT25) (Piatkowski et al. 1994). At the fixed station each $200 \mathrm{~m}$ layer from the surface to $1000 \mathrm{~m}$ was sampled by nominal $1 \mathrm{~h}$ downward oblique tows, twice in daylight and once in darkness. Volume filtered ranged between 131 and $279 \times 10^{3} \mathrm{~m}^{3}$ (mean 209 \pm 53) according to Wormuth \& Roper's (1983) recommendation. A further 7 hauls targetting acoustic layers were made as follows: (1) $50 \mathrm{~m}, 30 \mathrm{~min}$, daylight $(\times 2)$; (2) 300 to $350 \mathrm{~m}, 45 \mathrm{~min}$, daylight; (3) 375 to $400 \mathrm{~m}$, 20 min, daylight; (4) $600 \mathrm{~m}, 30 \mathrm{~min}$, daylight; (5) $50 \mathrm{~m}$, 15 min, darkness; (6) 50 to $100 \mathrm{~m}, 15 \mathrm{~min}$, darkness.

Horizontal-Antarctic multiple plankton sampler (H-AMPS): The opening/closing H-AMPS with a mouth aperture of $2 \mathrm{~m}^{2}$ and a mesh size of $1.5 \mathrm{~mm}$ was deployed in a vertical series. At the fixed station each $100 \mathrm{~m}$ layer from the surface to $600 \mathrm{~m}$ was sampled by nominal 30 min downward oblique tows twice in daylight and once in darkness.

Neuston net: A rectangular frame net with a mouth aperture of $1 \mathrm{~m}^{2}$ and a mesh size of $5 \mathrm{~mm}$ was deployed in the surface layer from the foredeck. Six daylight and 6 darkness hauls of 30 min each were carried out in the course of the study.

Cephalopod mantle length (ML) was measured to $1 \mathrm{~mm}$. If only the head was recovered the beak lower rostral length (LRL) was measured to $0.1 \mathrm{~mm}$ and $\mathrm{ML}$ estimated using equations in Clarke (1986), Rodhouse \& Yeatman (1990) and Rodhouse et al. (1990). Maturity was defined according to Lipinski (1979). Stomach contents were identified visually and data reported as percent occurrence (proportion of the total specimens of each cephalopod species in which each prey type was found).

Oceanographic data. Two CTD (Neil Brown Mk III) transects were undertaken to characterise the mesoscale oceanographic regime of the area. These transects were specifically sited across the region of biological interest, and were determined from the position of foraging predators fitted with PTT satellite tags. The orientation of the transects was a compromise between running as normal as possible to the major current flow and the local isobaths. CTD Transect 1 started at $49^{\circ} 42^{\prime} \mathrm{S}, 37^{\circ} 41^{\prime} \mathrm{W}$ and finished at $50^{\circ} 10^{\prime} \mathrm{S}, 36^{\circ} 39^{\prime} \mathrm{W}$; CTD Transect 2 started at $49^{\circ} 27^{\prime} \mathrm{S}, 36^{\circ} 26^{\prime} \mathrm{W}$ and finished at $50^{\circ} 13^{\prime} \mathrm{S}, 35^{\circ} 40^{\prime} \mathrm{W}$. Transects 1 and 2 consisted of 10 and 11 CTD stations respectively, with both having a nominal $10 \mathrm{~km}$ spacing between stations. The depths of the CTD casts varied; all casts were to at least $1000 \mathrm{~m}$ with intermittent profiles to near bottom. Expendable Bathythermographs (XBTs) (T7: range $760 \mathrm{~m}$ ) were deployed approximately half way between the CTD stations and also at a nominal $5 \mathrm{~km}$ spacing on passage between CTD Transects 1 and 2 (XBT Transect 1). This crossed the major current flow in an oblique direction, but nevertheless added extra oceanographic coverage for the area.

At each CTD station water bottle samples were taken at standard depths between the surface and $200 \mathrm{~m}$; additional samples were also taken at depths between $200 \mathrm{~m}$ and the bottom of the cast. 


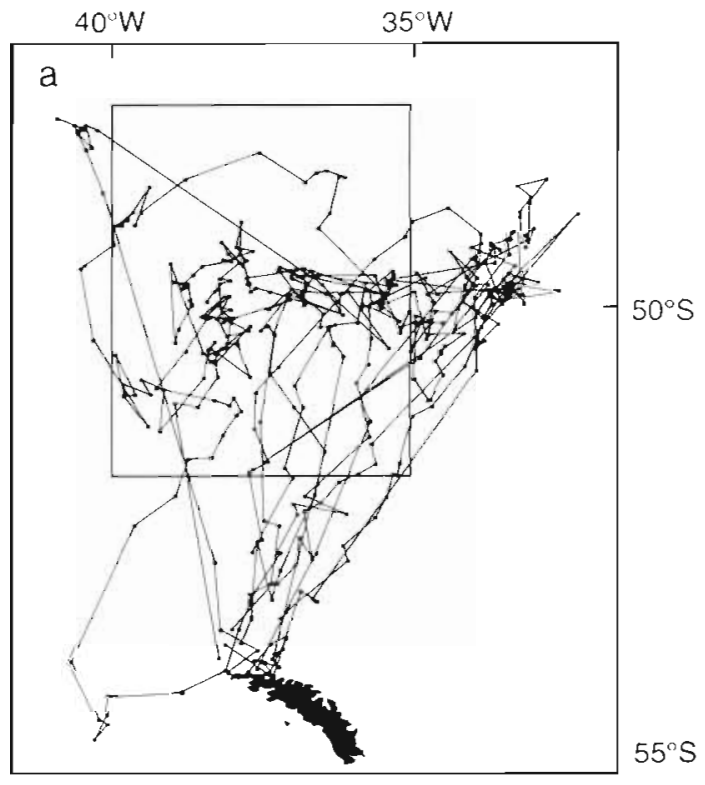

Fig. 2. (a) Tracks of satellite tagged grey-headed albatrosses from breeding colony at Bird Island, South Georgia during late January-early March 1994; (b) detail showing individual PTT position fixes, the waypoint (WP) of the fixed station for net sampling programme and bathymetry

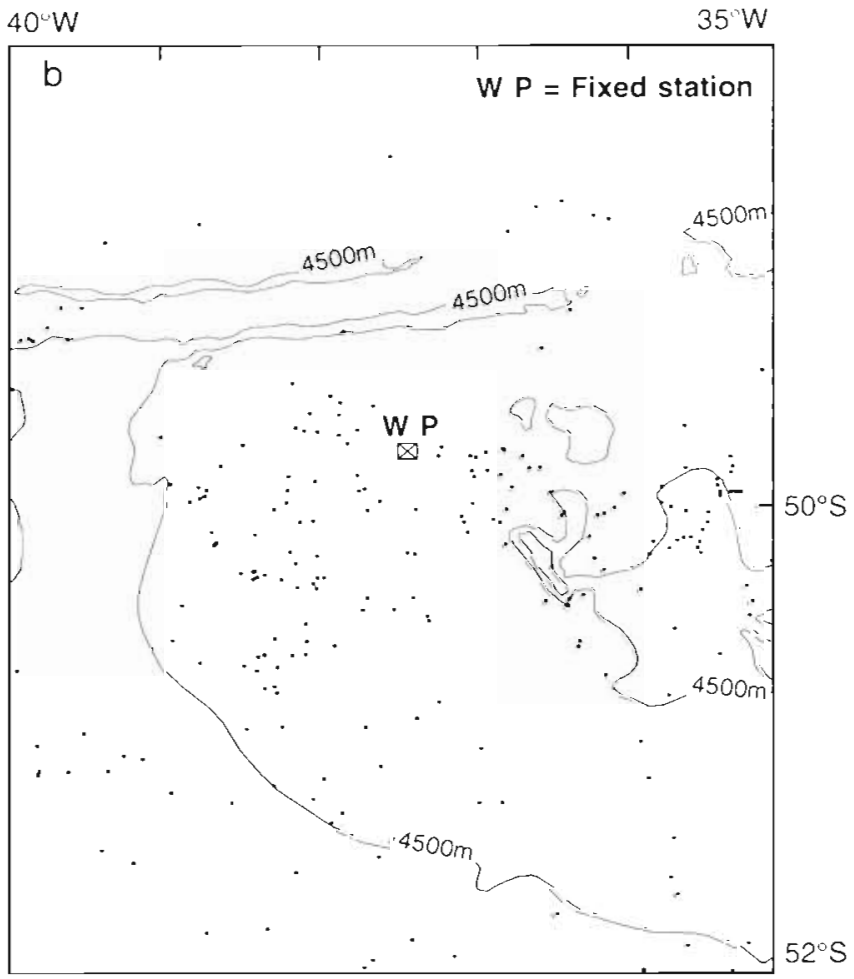

prey of D. melanophrys at Bird Island (Rodhouse \& Prince 1993), none was recovered from these samples.

Of the 8 completed foraging trips by Diomedea chrysostoma tracked in 1994 prior to the sampling programme, 7 were made to the PFZ to the north of South Georgia. The 8th was made to the south and is not considered further here. The 7 tracks made to the PFZ are shown in Fig. 2 along with a larger scale plot of individual PTT position fixes. Spacing of fixes indicates that the birds were travelling to the north and concentrating their foraging along the east/west axis of the PFZ at a latitude of $\sim 50^{\circ} \mathrm{S}$.

Cephalopods recovered from regurgitations of untagged Diomedea chrysostoma and D. melanophrys feeding their chicks at Bird Island in 1994 are given in Fig. 3. The cephalopod prey of both species was dominated by Martialia hyadesi and smaller numbers of Galiteuthis glacialis. There was no significant difference ( $t$-test: $p>0.10$ ) between the mean ML of $M$. hyadesi from the 2 species of albatross. Nor was there any significant difference ( $p>0.10$ ) between the mean ML of $M$. hyadesi from $D$. melanophrys in 1994 and those from $D$. chrysostoma in 1993. The mean ML of $M$. hyadesi from $D$. chrysostoma in 1994 was significantly less than from the same species in 1993 ( $t$-test: $p<0.01$ ), but the difference of $23 \mathrm{~mm}$ was small. 
Table 1 Cephalopods recovered from food samples delivered to chicks at Bird Island, South Georgia (Antarctic) by satellite-tagged grey-headed and blackbrowed albatrosses between late January and early March 1993

\begin{tabular}{|c|c|c|c|c|c|c|}
\hline \multirow[t]{2}{*}{ Cephalopod species } & \multicolumn{3}{|c|}{ Grey-headed albatross } & \multicolumn{3}{|c|}{ Black-browed albatross } \\
\hline & $\begin{array}{c}\text { Estimated } \\
\text { ML, mm } \\
\text { (range) }\end{array}$ & Mean & $\mathrm{n}$ & $\begin{array}{c}\text { Estımated } \\
\text { ML, mm } \\
\text { (range) }\end{array}$ & Mean & $\mathrm{n}$ \\
\hline Gonatus antarcticus & 243 & & 1 & & & \\
\hline Moroteuthis knipovitchi & & & & 279 & & 1 \\
\hline Martialia hyadesi & $218-306$ & 242 & 10 & & & \\
\hline Galiteuthis glacialis & 207 & & 1 & & & \\
\hline Parelodene turqueti & & & & 60 & & 1 \\
\hline
\end{tabular}

such as squid, with a target strength (TS) of around -45 to $-50 \mathrm{~dB}$ (Arnaya et al. 1989a, b), this would correspond to a numerical density of 0.01 to $1 \mathrm{ani}$ mals $100 \mathrm{~m}^{-3}$.

\section{Cephalopods from net samples}

The 4 nets caught a total of 109 specimens of pelagic squid representing 10 species (Fig. 3). The largest and most conspicuous was Martialia

\section{Acoustics}

The vertical pattern at the fixed station consisted of 3 main iayers of acoustic targets (Fig. 4). A shallow layer, usually about 20 to $50 \mathrm{~m}$ thick, was found between 10 and $100 \mathrm{~m}$ throughout most of the study period. A deep layer about 100 to $150 \mathrm{~m}$ thick was found centred around depths of 600 to $700 \mathrm{~m}$. A 3rd layer was frequently found between the deep and shallow layers. The depth and thickness of this middle layer was quite variable but a typical daytime depth layer was 300 to $400 \mathrm{~m}$. However, during some daylight net hauls there was no obvious middle layer visible on the echo-chart. The thickness of the middle layer also varied from $<20$ to $150 \mathrm{~m}$ but overall density was usually the least of the 3 layers. At times, mostly during daylight, very dense, relatively small targets were found either imbedded within the middle layer (Fig. 4a) or within the top $100 \mathrm{~m}$ (Fig. 4b).

The 3 acoustic layers appeared to occupy 3 distinct depth zones with little overlap during either day or night. At sunset (21:00 h) on 8 February 1994 we observed the deep layer dividing. The lower part remained centred around $600 \mathrm{~m}$ while the upper migrated up towards the middle layer. At the same time the mid layer appeared to diffuse. By 22:30 h this upward migrating layer had reached 300 to $400 \mathrm{~m}$, replacing the middle layer in the water column, and then starting to scatter and become very diffuse.

Acoustic backscatter from organisms within the 3 layers was typically in the range -69 to $-75 \mathrm{~dB}$ at $38 \mathrm{kHz}$. For animals

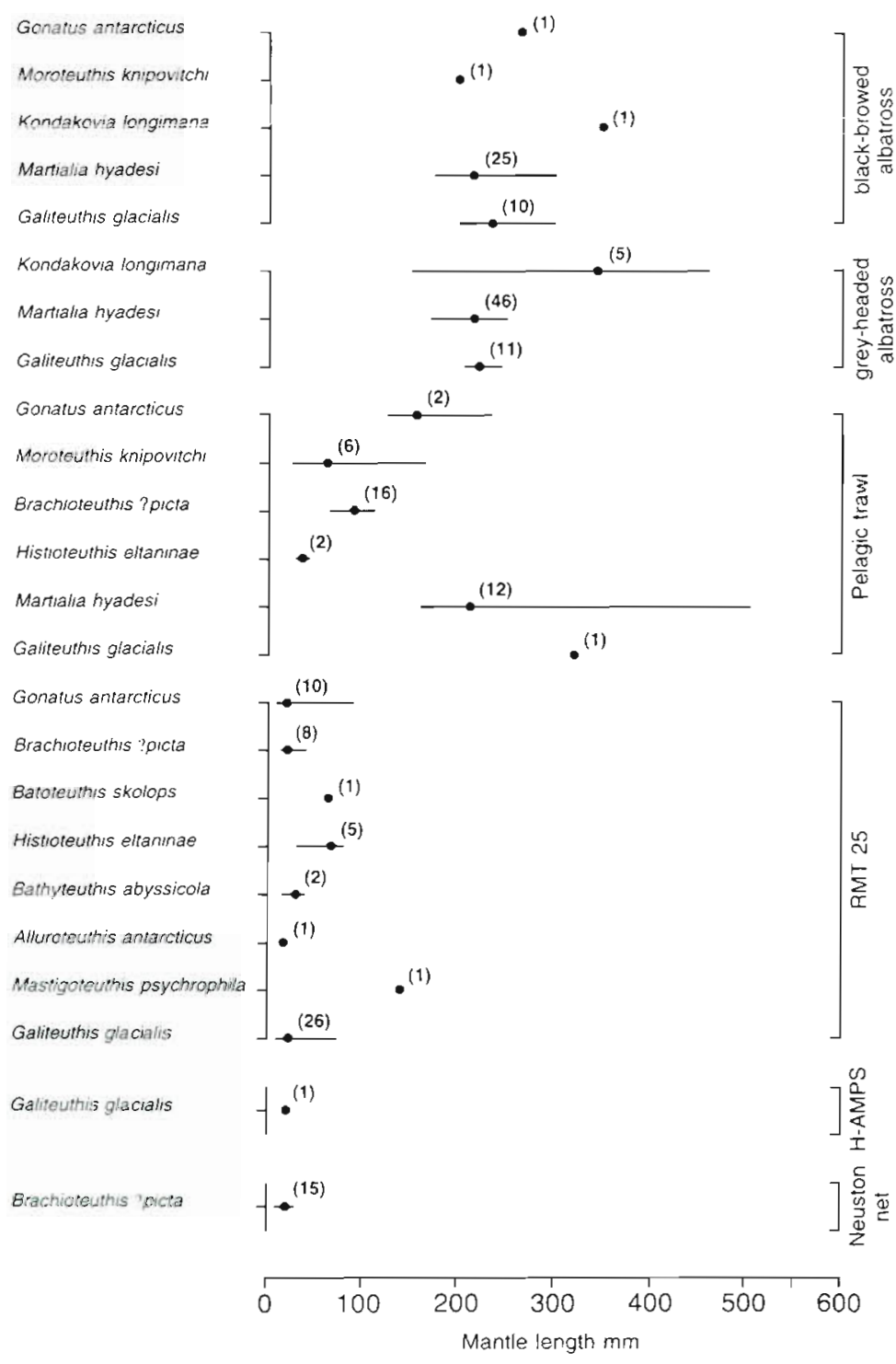

Fig. 3. Cephalopods from research net hauls at Antarctic Polar Frontal Zone and from predators sampled at Bird Island in February 1994 (median mantle length and range; mantle length estimated from beak lower rostral length in the case of predator samples] 


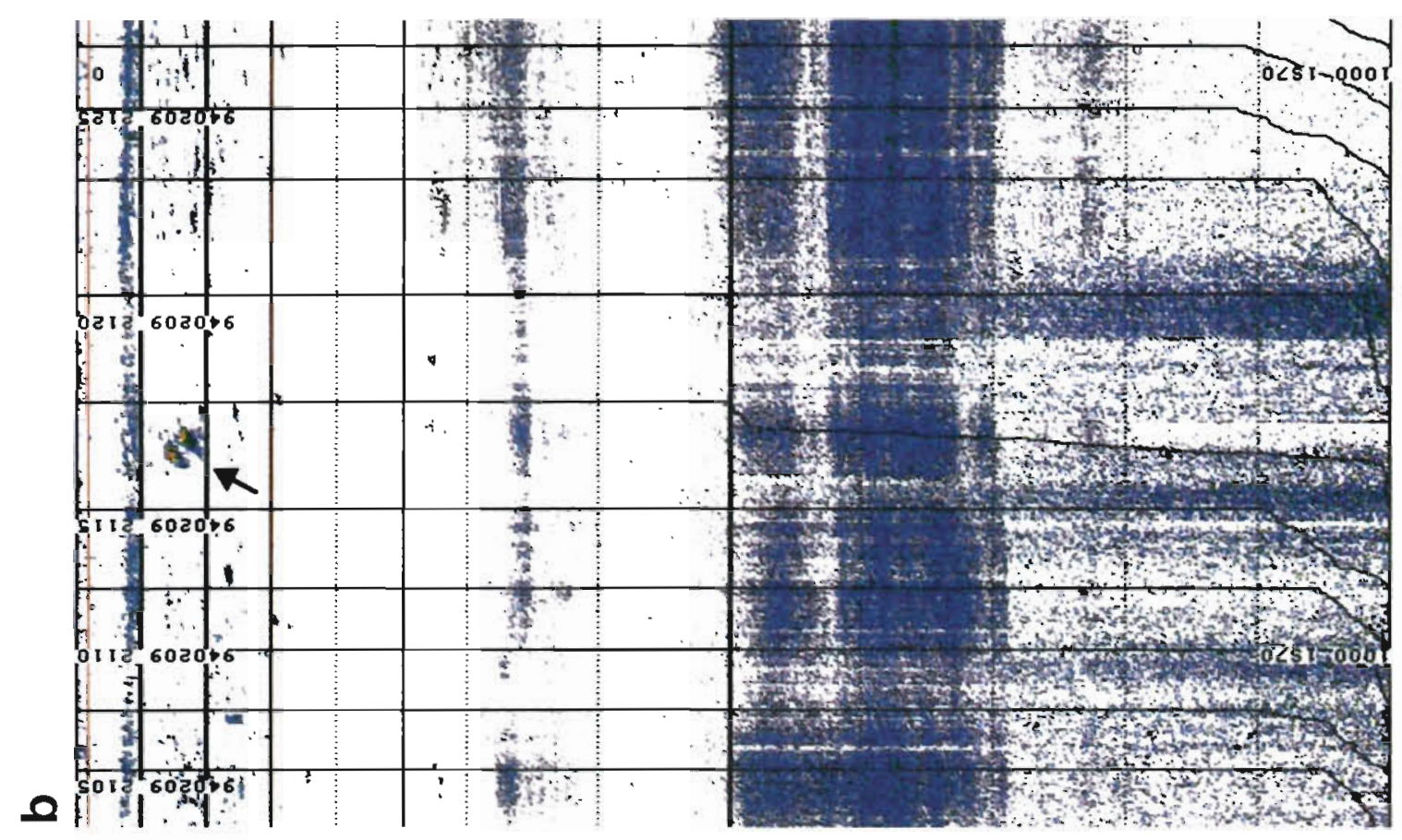

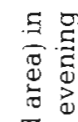

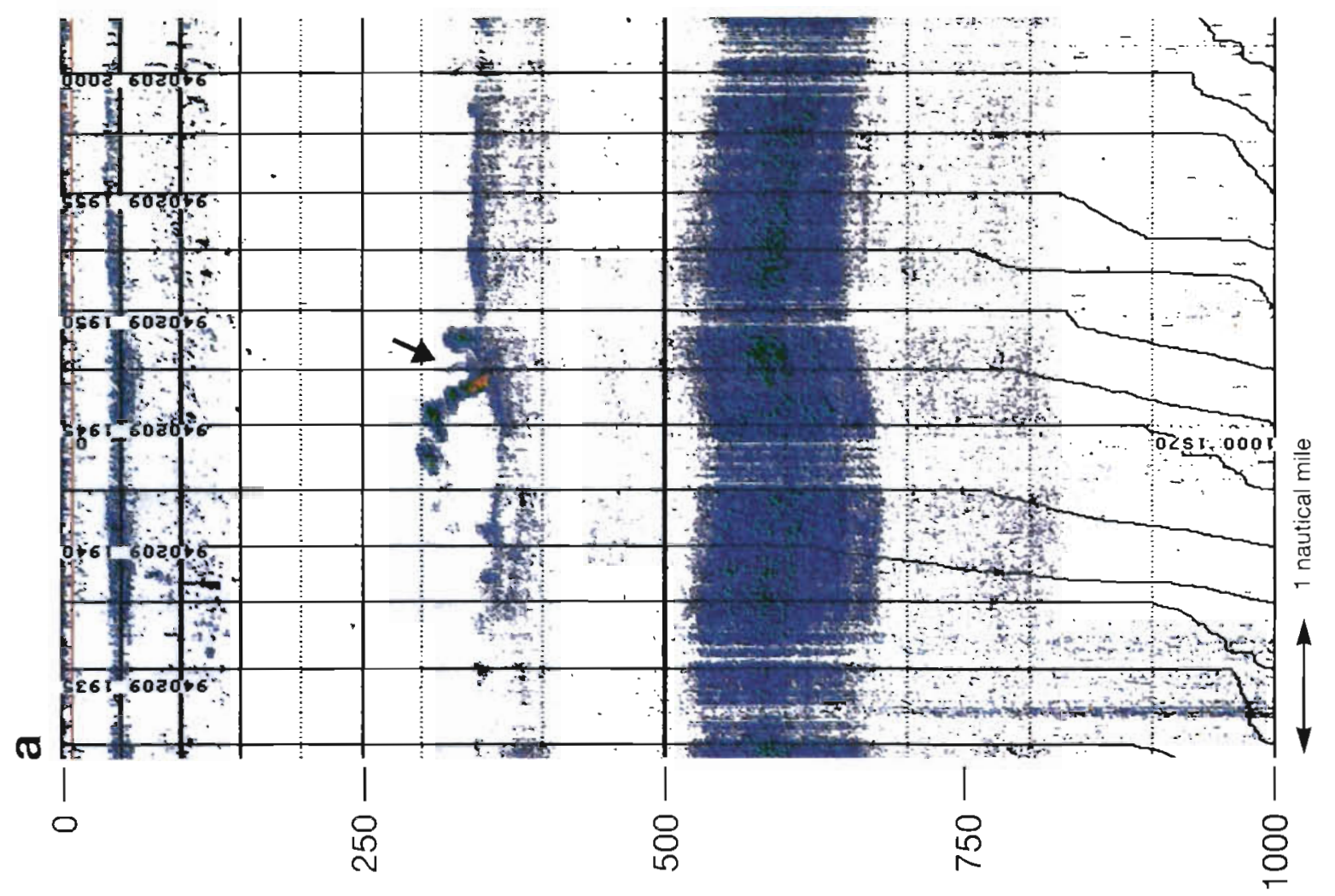

(wi) yłdeg 
hyadesi, caught with the pelagic trawl. Most specimens fell in the size range 161 to $248 \mathrm{~mm}$ ML and there was a single much larger specimen with a ML of $506 \mathrm{~mm}$. This could not be identified with certainty because the head was stolen by an albatross as the net came aboard but the shape of the mantle and fins, along with the characteristic purple skin, left little doubt as to its identity. The male:female ratio of the sample was $1: 2$. The smaller specimens of both sexes were all at maturity stage II (immature). The single large specimen (ML = $506 \mathrm{~mm}$ ) was a female at maturity stage III (preparatory). Most specimens were removed from meshes in the wings of the net and few reached the codend, suggesting that the net considerably undersampled the population. There was no significant difference ( $t$-test: $p>0.10$ ) between the $M L$ of $M$. hyadesi caught by the net (excluding the $506 \mathrm{~mm}$ ML specimen) and those sampled from Diomedea chrysostoma. The mean ML of $M$. hyadesi caught by the net was $23 \mathrm{~mm}$ less than those from black-browed albatrosses and this difference was significant ( $t$-test: $p<0.05)$.

Among the other species of squid the largest were also caught by the pelagic trawl, followed in order of decreasing size by the RMT25, HAMPS and neuston net. There was little overlap between the size ranges sampled by the different nets (Fig. 5). The RMT25 caught the greatest number of species but did not sample 2 species, Martialia

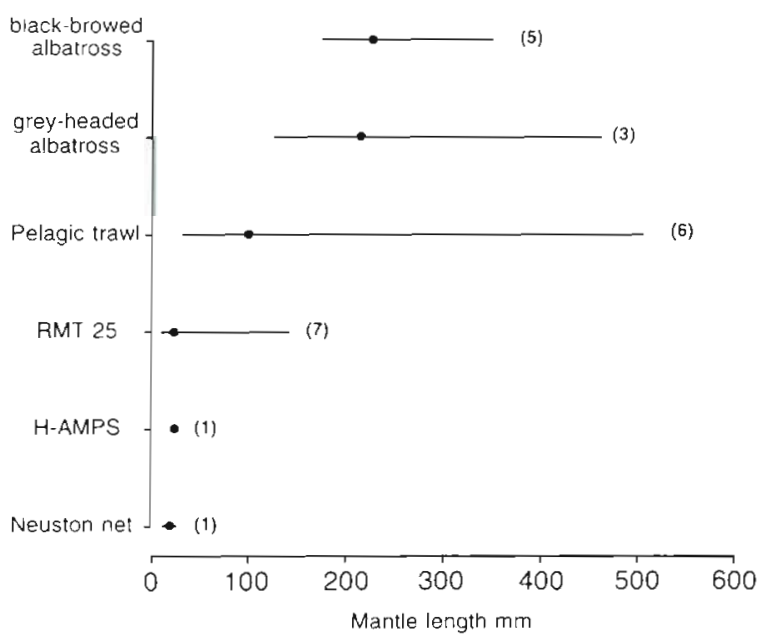

Fig. 5. Comparison of size of cephalopods and numbers of species trom predators sampled at Bird Island and by nets at the Antarctic Polar Frontal Zone in February 1994 (median mantle length and range; mantle length estimated from beak lower rostral length in the case of predator samples)

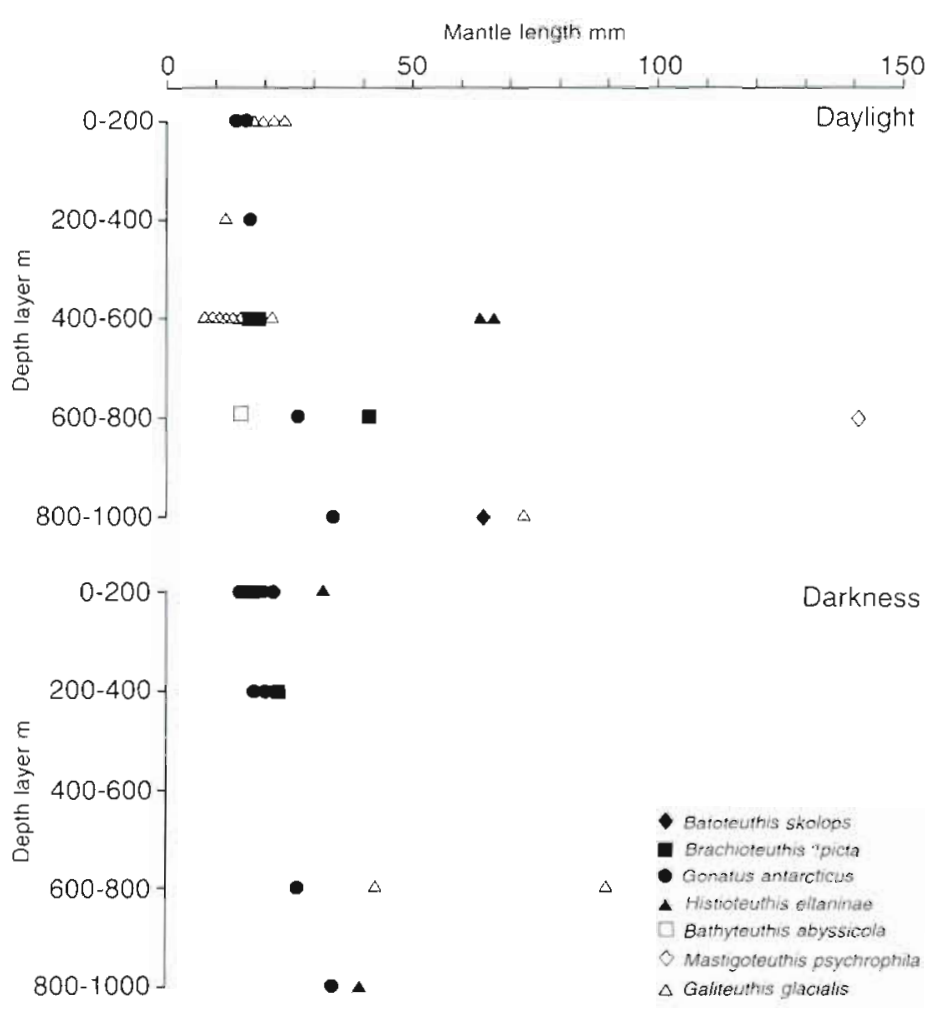

Fig. 6. Vertical distribution of cephalopods at the Antarctic Polar Frontal Zone in February 1994, sampled by the RMT25

hyadesi and Moroteuthis knipovitchi, which were only caught with the pelagic trawl.

The commonest species in the net samples was Brachioteuthis ?picta, which is rarely, if ever, taken by albatrosses. Galiteuthis glacialis was caught by all nets, except the neuston net, and was present in the regurgitations of both albatross species; the single specimen from the pelagic trawl was of similar size to the samples from albatrosses. Gonatus antarcticus was caught by the 2 larger nets as well as by a Diomedea melanophrys and those from the pelagic trawl and the albatross were of similar size.

The RMT25 vertical series (Fig. 6) showed that smaller Gonatus antarcticus and Galiteuthis glacialis are present throughout the water column to $1000 \mathrm{~m}$. There is some evidence that Brachioteuthis ?picta and Histioteuthis eltaninae make an upward vertical migration in darkness. Specimens of Batoteuthis skolops, Bathyteuthis abyssicola and Mastigoteuthis psychrophila were all caught at depths $>600 \mathrm{~m}$.

The data from nets that targeted specific layers are given in Table 2. The neuston net and the RMT25 catches were similar in composition to those made at the same depths with the RMT25 during the vertical series. The pelagic trawl caught relatively large specimens of Gonatus antarcticus, Moroteuthis knipovitchi, 
Table 2. Cephalopods caught by pelagic trawl, RMT25 and neuston net targeting acoustic layers at the Antarctic Polar Frontal Zone in February 1994

\begin{tabular}{|c|c|c|}
\hline Cephalopod species & $\begin{array}{l}\text { Number of } \\
\text { specimens }\end{array}$ & $\begin{array}{c}\text { Mantle length, } \\
\text { mm (range) }\end{array}$ \\
\hline $\begin{array}{l}\text { Neuston net surface (darkness } \\
\text { Brachioteuthis?picta }\end{array}$ & 15 & $12-24$ \\
\hline $\begin{array}{l}\text { RMT25 } 375 \text { to } 400 \mathrm{~m} \text { (daylight) } \\
\text { Galiteuthis glacialis }\end{array}$ & t) & $15-23$ \\
\hline $\begin{array}{l}\text { RMT25 } 600 \mathrm{~m} \text { (daylight) } \\
\text { Brachioteuthis ?picta } \\
\text { Galiteuthis glacialis } \\
\text { Histioteuthis eltaninae }\end{array}$ & $\begin{array}{l}3 \\
4 \\
2\end{array}$ & $\begin{array}{l}18-25 \\
16-24 \\
67-79\end{array}$ \\
\hline $\begin{array}{l}\text { Pelagic trawl } 0 \text { to } 100 \mathrm{~m} \text { (darkn } \\
\text { Gonatus antarcticus } \\
\text { Moroteuthis knipovitchi } \\
\text { Brachioteuthis?picta } \\
\text { Martialia hyadesl } \\
\text { Galiteuthis glacialis }\end{array}$ & $\begin{array}{r}\text { ness) } \\
1 \\
5 \\
15 \\
8 \\
1\end{array}$ & $\begin{array}{c}124 \\
48-62 \\
77-111 \\
175-214 \\
320\end{array}$ \\
\hline
\end{tabular}

Brachioteuthis ?picta, Martialia hyadesi and Galiteuthis glacialis in the 0 to $100 \mathrm{~m}$ layer in darkness. Most of the $M$. hyadesi $(66 \%)$ that were caught with the pelagic net were taken in that haul.

\section{Cephalopod stomach contents}

Stomach contents of each cephalopod species are given in Table 3. Crustaceans were the most frequent group, being present in all stomachs with contents, and they were the only prey present in all but 2 species of squid, Martialia hyadesi and Histioteuthis eltaninae. No crustaceans other than amphipods and copepods were identified. Euphausia superba was absent from the stomach contents. $M$. hyadesi also had remains of unidentifiable myctophid and squid species, and one specimen of $H$. eltaninae had cephalopod remains in the stomach.

\section{Oceanographic data}

On the basis of thermohaline stratification, 3 distinct water types can be distinguished to the north of South Georgia (Gordon et al. 1977). Features characteristic of the 3 water types are indicated on the temperature/ salinity plots for the CTD transects (Fig. 7).

Sub-Antarctic Zone. The SAZ is characterised by a gradual increase in salinity with depth. There is no temperature minimum ( $\mathrm{T}$-min), although there is a rapid decrease in temperature between 100 and $300 \mathrm{~m}$. Below this broad layer the water is nearly isothermal to $1000 \mathrm{~m}$. In Fig. 7 the rapid decrease in temperature is indicated by SAZ-dt, and the nearly isothermal layer by SAZ-il.

Polar Frontal Zone. The PFZ may be identified by numerous density compensating temperature and salinity inversions. These layers extend from approximately 100 to $400 \mathrm{~m}$. Below this layer, salinity gradually increases with depth, whereas temperature gradually decreases. In Fig 7 examples of the mesoscale variability associated with the temperature and salinity inversions are indicated by PFZ-dci

Antarctic Zone. The AAZ is characterised by a well developed T-min. Below the T-min, the salinity gradu-

Table 3. Percentage occurrence of prey types in the stomach contents of cephalopods caught at Antarctic Polar Frontal Zone in February 1994 (crustaceans = all crustaceans including those identified to lower taxon; copepod = copepods not identified to species)

\begin{tabular}{|c|c|c|c|c|c|c|c|c|}
\hline $\begin{array}{l}\text { Cephalopod } \\
\text { species }\end{array}$ & $\begin{array}{c}\text { Fish } \\
\text { (Myctophidae) }\end{array}$ & $\begin{array}{l}\text { Crusta- } \\
\text { ceans }\end{array}$ & Copepod & $\begin{array}{l}\text { Copepod } \\
\text { Euchaeta sp. }\end{array}$ & $\begin{array}{l}\text { Amphipod } \\
\text { Themisto } \\
\text { gaudichaudii }\end{array}$ & $\begin{array}{l}\text { Amphipod } \\
\text { Primno } \\
\text { macropa }\end{array}$ & $\begin{array}{l}\text { Cephalo- } \\
\text { pod }\end{array}$ & $\begin{array}{l}\text { Stomach } \\
\text { empty }\end{array}$ \\
\hline $\begin{array}{l}\text { Gonatus antarcticus } \\
\text { ML } 67-79 \mathrm{~mm}, \mathrm{n}=2\end{array}$ & & 50 & & & 50 & & & 50 \\
\hline $\begin{array}{l}\text { Moroteuthis knipovitchi } \\
\text { ML } 57-166 \mathrm{~mm}, \mathrm{n}=6\end{array}$ & & 83 & & & 17 & & & 17 \\
\hline $\begin{array}{l}\text { Brachoteuthis ?picta } \\
\text { ML } 31-111 \mathrm{~mm}, \mathrm{n}=20\end{array}$ & & 81 & 20 & 10 & 57 & & & 19 \\
\hline $\begin{array}{l}\text { Batoteuthis skolops } \\
\text { ML } 65 \mathrm{~mm}, \mathrm{n}=1\end{array}$ & & & & & & & & 100 \\
\hline $\begin{array}{l}\text { Histioteuthis eltaninae } \\
\text { ML } 67-79 \mathrm{~mm}, \mathrm{n}=2\end{array}$ & 50 & 50 & & & & & 50 & \\
\hline $\begin{array}{l}\text { Bathyteuthis abyssicola } \\
\text { ML } 43 \mathrm{~mm}, \mathrm{n}=1\end{array}$ & & & & & & & & 100 \\
\hline $\begin{array}{l}\text { Martialia hyadesi } \\
\text { ML } 161-506 \mathrm{~mm}, \mathrm{n}=10 \\
\text { Mastiqoteuthis psychroph }\end{array}$ & hila ${ }^{27}$ & 100 & & & & 9 & 27 & \\
\hline $\begin{array}{l}\text { ML } 141 \mathrm{~mm}, \mathrm{n}=1 \\
\text { Galiteuthis glacialis }\end{array}$ & & & & & & & & LŨ \\
\hline $42-91 \mathrm{~mm}, \mathrm{n}=3$ & & & & & & & & 100 \\
\hline
\end{tabular}



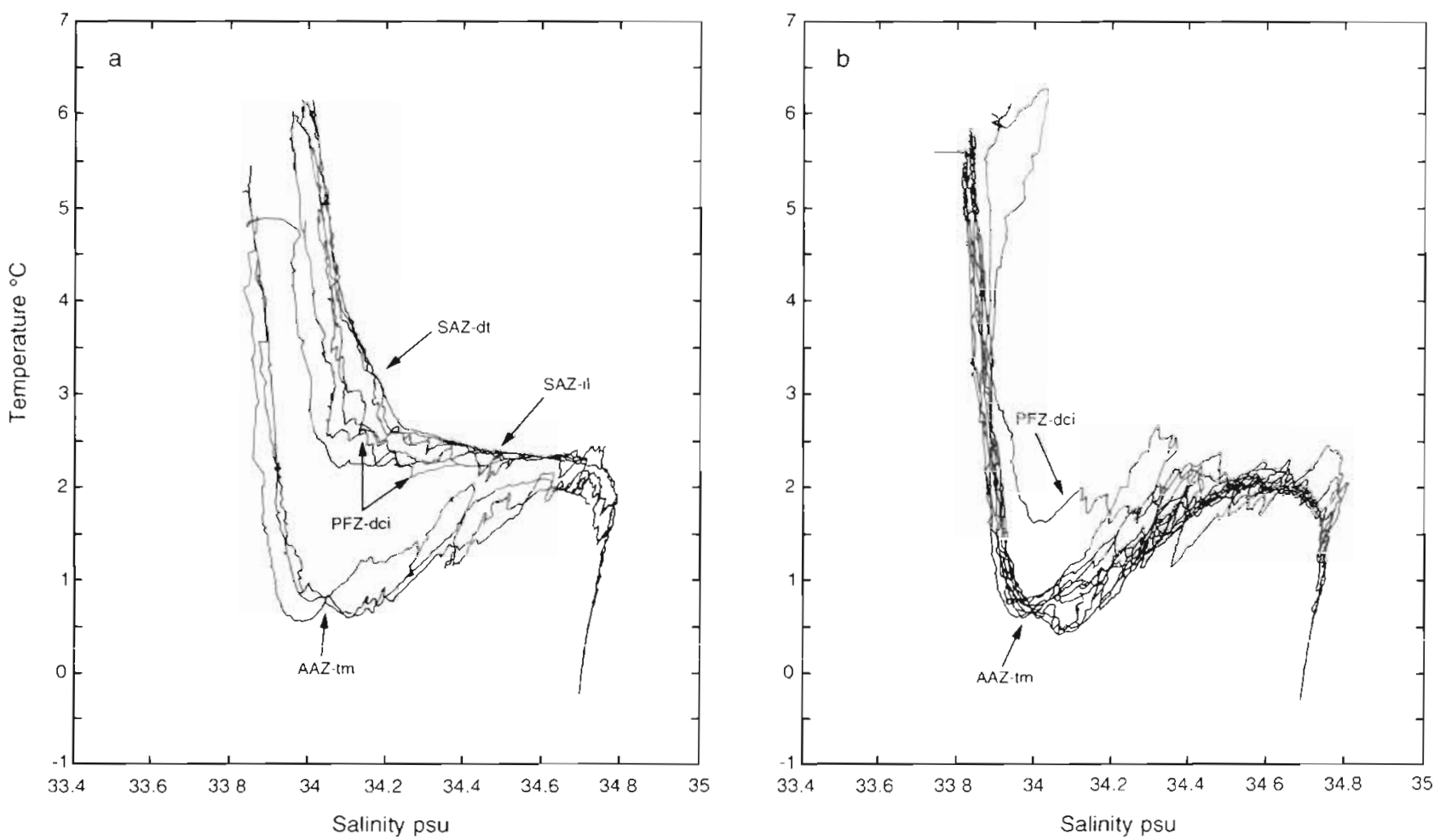

Fig. 7. (a) Temperature/salinity (T/S) plot along CTD Transect 1 ; (b) T/S plot along CTD Transect 2 (dt: decrease in temperature; il: isothermal layer; dci: density compensated inversions layers; tm: temperature minimum)

ally increases with depth. The T-min is indicated by AAZ-tm in Fig. 7 .

Temperature and salinity profiles along the transects indicate substantial mesoscale variability. AAZ water was found towards the southern end of both CTD Transect 1 and XBT Transect 1 and across the centre of CTD Transect 2, whilst SAZ water occurred to the north of CTD Transect 1; PFZ water was found on all transects. Substantial vertical variability is also evident, with interleaving of the main water types.

The density profiles $(\sigma t)$ along CTD Transects 1 and 2 (Fig. 8) are not consistent with crossing a single mesoscale hydrographic feature, but suggest that a complex feature or set of features was sampled. From CTD Transect 1 , the isopycnals ( $\sigma t$ surfaces) indicate strong density differences, with the $27.4 \mathrm{~kg} \mathrm{~m}^{-3}$ surface occurring at $200 \mathrm{~m}$ toward the southern end of the transect, compared to $400 \mathrm{~m}$ at the centre and $350 \mathrm{~m}$ at the northern end. Such a density gradient is indicative of an easterly flow at the southern end of the transect and a westerly flow at the northern end. In comparison, along CTD Transect 2, the 27.4 surface is at $300 \mathrm{~m}$ at the southern end of the transect, at $200 \mathrm{~m}$ near the centre and at $250 \mathrm{~m}$ at the northern end. Such density gradients indicate an easterly flow at the northern end of the transect and a westerly flow at the southern end. The horizontal displacement of the
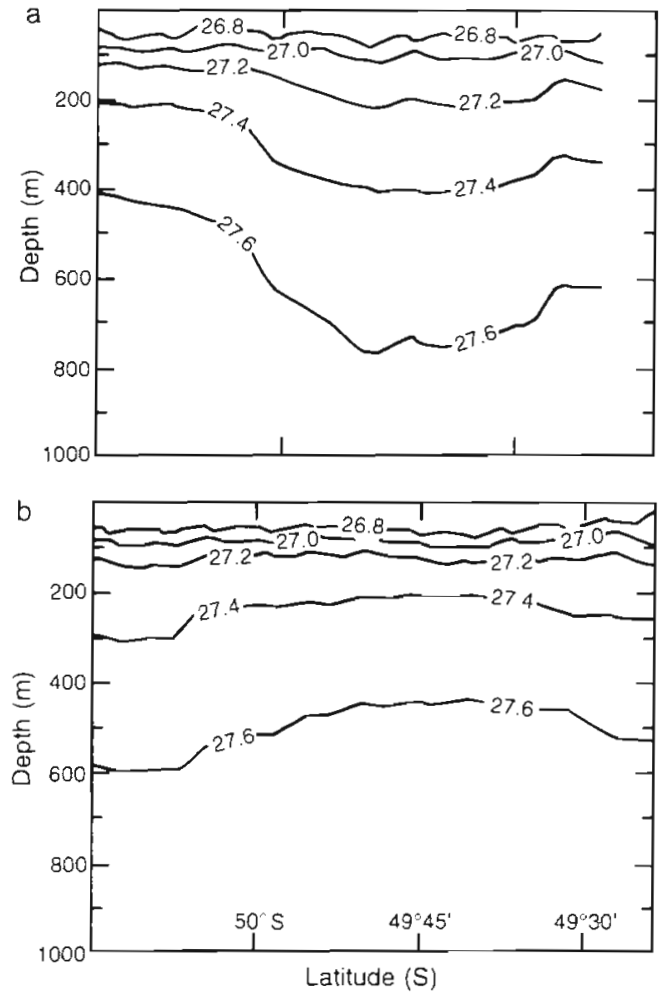

Fig. 8. (a) Density profile $(\sigma t)$ Transect 1; (b) density profile $(\sigma t)$ Transect 2 
ship whilst on station during the transects was also consistent with these flows.

Calculation of geostrophic flow at $200 \mathrm{~m}$ (referenced to $1000 \mathrm{~m}$ ) confirms the existence of these flows, with velocities approaching $0 \mathrm{~cm} \mathrm{~s}^{-1}$ on CTD Transect 2, to as much as $40 \mathrm{~cm} \mathrm{~s}^{-1}$ on CTD Transect 1.

\section{Remotely sensed sea suriace temperature}

A SST image timed at the start of CTD Transect 2 is shown in Fig. 9. The image is entirely consistent with the oceanographic data collected on the ship and provides considerable clarification of the PFZ.
To the north of South Georgia, the area covered by CTD Transects 1 and 2 is largely cloud free. In this area the PFZ includes a large number of mesoscale features over the northern end of the Northeast Georgia Rise and near the gap in the Falkland Ridge. The meander or eddy at $37^{\circ} 30^{\prime} \mathrm{W}, 50^{\circ} 00^{\prime} \mathrm{S}$ matches very closely with CTD Transect 1 ; and suggests the existence of a warm core ring with approximate dimensions $140 \times 80 \mathrm{~km}$. The AAZ water passing east of this meander streams out over the gap in the Falkland Ridge. The middle of CTD Transect 2 cuts across the AAZ water, whilst the southern end lies close to a further mesoscale feature situated at $35^{\circ} 00^{\prime} \mathrm{W}$, $50^{\circ} 00^{\prime} \mathrm{S}$.
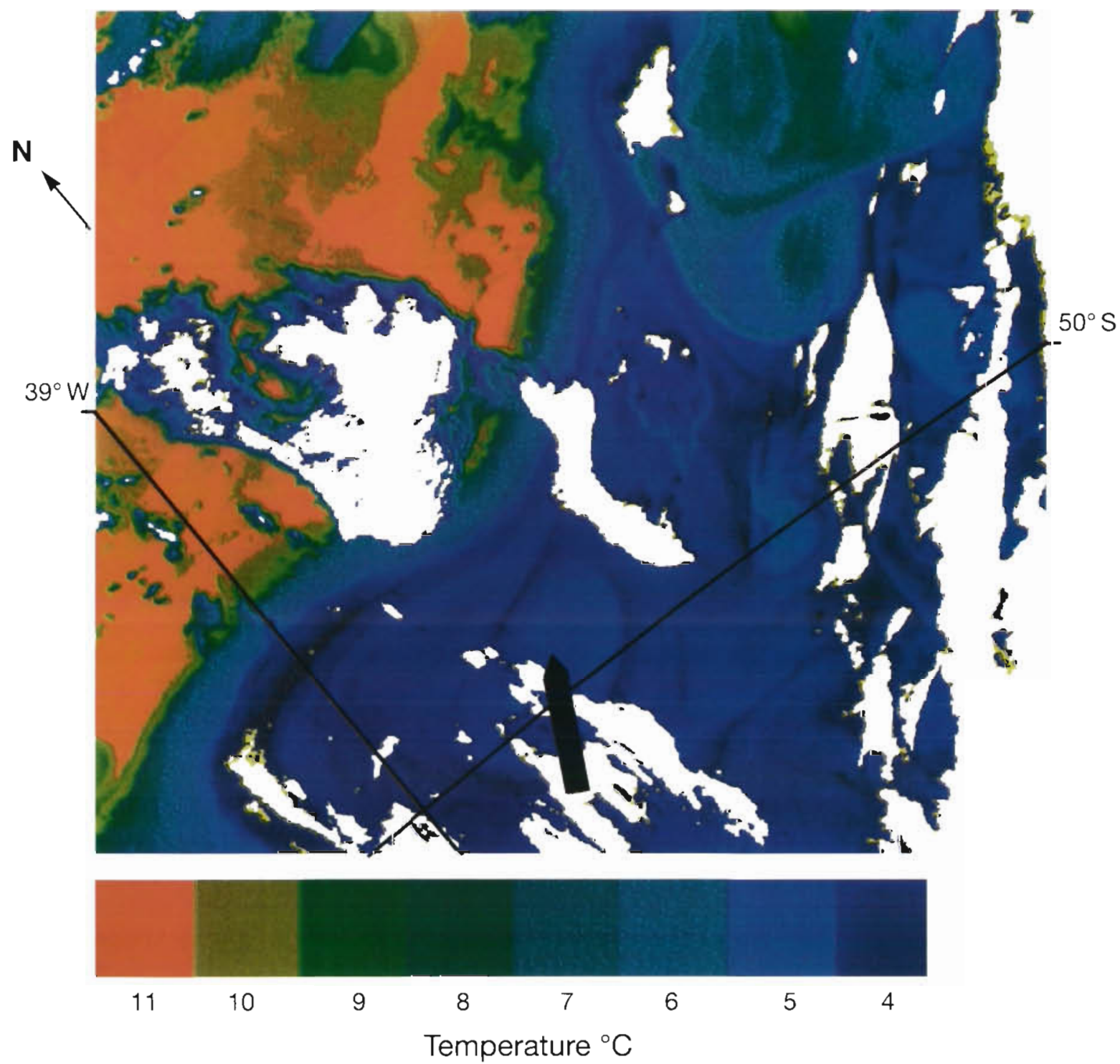

Fig. 9. False colour AVHRR image of sea surface temperature showing mesoscale features over northern end of Northeast Georgia Rise near the gap in the Falkland Ridge. Meander or eddy at $37^{\circ} 30^{\prime} \mathrm{W}, 50^{\circ} 00^{\prime} \mathrm{S}$, within which the cephalopod community was sampled, is indicated with an arrow. Area covered by image is approximately $610 \times 550 \mathrm{~km}$ 


\section{DISCUSSION}

We have demonstrated that it is possible to use satellite-tagged foraging seabirds to identify the location of their cephalopod prey, to locate associated acoustic marks and sample their prey using a commercial scale pelagic trawl. We have discovered that Diomedea chrysostoma and possibly D. melanophrys, feeding their chicks at Bird Island with Martialia hyadesi and associated squid species, are primarily foraging in the vicinity of the PFZ. Furthermore, the cephalopod community was found in the same area as transitory mesoscale oceanographic features possibly related to the bathymetry of the North Scotia Ridge and Falkland Plateau. The apparent association of the mesoscale oceanographic features with the bathymetry suggests that they may be predictable foraging locations for the cephalopods and their predators.

The cephalopod community in the upper $100 \mathrm{~m}$ of the water column sampled with the pelagic trawl at night in the region of the PFZ where the albatrosses were foraging agrees well, both in terms of species composition and size range, with food samples collected from adult albatrosses at Bird Island during the present study, in 1993 and in earlier comprehensive studies of the cephalopod prey of these albatross species (Clarke \& Prince 1981, Rodhouse et al. 1990, Rodhouse \& Prince 1993). The albatrosses' prey is largely comprised of Martialia hyadesi with small numbers of other species. Of these, Galiteuthis glacialis, Gonatus antarcticus and Histioteuthis eltaninae were caught in the pelagic net and Alluroteuthis antarcticus was caught in the RMT25. Other squid species, Kondakovia longimana and Chiroteuthis sp., are of minor importance in the albatrosses' diet. They were not caught during the present study but have been sampled by nets in earlier studies in the PFZ (Rodhouse 1991, Rodhouse \& Piatkowski 1995). However, the most frequent squid in the net samples, Brachioteuthis ?picta, is entirely absent from the albatrosses' diets. This is a relatively small species, and thus may not be of interest to albatrosses, although it is numerically the most abundant species of squid in the diet of southern elephant seals (Rodhouse et al. 1992a).

The pelagic net caught only a small number of Martialia hyadesi but exploratory jigging trials at the PFZ in 1989 (Rodhouse 1991) have shown that high densities of the species occur in the region. Furthermore, the South Georgia population of Diomedea chrysostoma has been reliabiy estimated to consume some 14000 to $19000 \mathrm{t}$ of $M$. hyadesi per annum and other, less reliable, estimates of consumption by other predator species in the Scotia Sea are much higher (Rodhouse et al. 1993). The brief sampling with the pelagic net described here undoubtedly underestimated densities of the highly mobile and aggregated $M$. hyadesi at the PFZ.

Although the pelagic net caught a relatively small number of Martialia hyadesi, it revealed information that has not previously been available about the species from samples caught by commercial squid jiggers. The largest specimens sampled previously have been $<340 \mathrm{~mm}$ ML whereas the pelagic trawl caught a specimen of $>500 \mathrm{~mm} \mathrm{ML}$ during the present study. The specimen from the trawl was a female that had not reached full sexual maturity which supports the conclusion, derived from statolith ageing studies, that $M$. hyadesi has a life span of more than 1 yr, possibly 2 (Rodhouse 1991, Rodhouse et al. 1994b). The life cycle of $M$. hyadesi is poorly understood. The small numbers of young juveniles caught on the edge of the Patagonian Shelf in the vicinity of the Falkland Islands (Rodhouse et al. 1992b) suggest that spawning takes piace in the northwestern part of the Scotıa sea. There are 2 known areas of distribution of the early adult phase, the PFZ and the Patagonian Shelf edge. However, there is no information about distribution of juveniles or the large squid in what is presumed to be the 2 nd year of the life cycle.

The presence of Martialia hyadesi and other cephalopod species associated with a warm core ring at the PFZ (Fig. 9) is consistent with observations elsewhere that mesoscale distribution of pelagic squid, especially ommastrephids, is related to frontal systems, and in particular to the eddy structure at fronts (Sugimoto \& Tameishi 1992). Furthermore there is evidence that the distribution of another cephalopod predator, the sperm whale Physeter catodon, is associated with warm core rings on the northern edge of the Gulf Stream (Waring et al. 1993). At the PFZ the pelagic nekton community is dominated by small crustaceans, larger myctophid fish, the tunicate Salpa thompsoni and cnidarians (Piatkowski et al. 1994, Rodhouse et al. 1994a, F. Pagès, M. G. White, P. G. Rodhouse unpubl.). Smaller cephalopods prey on the crustaceans but the presence of larger $M$. hyadesi appears to be associated with the high densities of myctophid fish. Warm core rings presumably provide favourable conditions for the community that the cephalopods exploit.

At the PFZ the dominant top predators in the epipelagic system are cephalopods and not fish (Rodhouse \& White 1995). The composition of the PFZ pelagic fish community is characterised by the absence of epipelagic families and typical members of the pelagic food-web in temperate and tropical seas. In the South Pacific there is an oceanic epipelagic fish community and some members of this, notably the slender tuna Allothunnus fallai (Yatsu 1995) and the Peruvian jack mackerel Trachurus symmetricus murphyi (Elizarov et al. 1993), extend into Sub-Antarctic waters but 
do not penetrate south of the Sub-Antarctic Front into the PFZ. There is no evidence that epipelagic fish are present in the PFZ in the Atlantic sector. Explanations for the absence of epipelagic fish in Antarctic waters, reviewed by Eastman (1993), include physiological constraints on white and red muscle physiology, the lack of a swim bladder in the predominant suborder of Antarctic fish, the Notothenioidei, and the highly seasonal food supply which would limit planktivores. There is no information on cephalopod muscle physiology at low temperatures. Buoyancy constraints may be minimised in ommastrephid and other muscular squid because they have no bones, they possess a large oil-filled digestive gland and they generate hydrodynamic lift with their fins and swimming keels. These constraints are eliminated in the bathyscaphoid cranchiids which possess ammoniacal coelomic fluids, and in species with ammoniacal musculature such as the histioteuthids.

The life cycles of Martialia hyadesi and other cephalopods at the PFZ are poorly understood and the ecology of this region has received scant attention from biological oceanographers. It is an important system for several Antarctic higher predators and has apparent potential to support commercial fisheries. Understanding the relationship between cephalopod life cycles and variability within the physical oceanographic regime of the PFZ is an important requirement for the rational management of this ecosystem.

Acknowledgements. We thank Trucia Gilmour, Carolyn Simon, John Croxall, Andy Wood, Keith Reid, Nick Huin, Mark Brandon and Andy Clarke (BAS Marine Life Sciences Division), Tom Lachlan-Cope and Richard Siddans (BAS Remote Sensing Group) and the ship's company RRS 'James Clark Ross' for their various contributions to this research. Development of the work station GIS was funded in part by the Worldwide Fund for Nature (UK). We thank 3 anonymous referees for their constructive criticism.

\section{LITERATURE CITED}

Adams NJ, Klages NT (1987) Seasonal variation in the diet of the king penguin (Aptenodytes patagonicus) at subAntarctic Marion Island. J Zool Lond 212:303-324

Arnaya IN, Sano N, lida K (1989a) Studies on acoustic target strength of squid III. Measurements of the mean target strength of small live squid. Bull Fac Fish Hokkaido Univ 40:100-115

Arnaya IN, Sano N, Iida K (1989b) Studies on acoustic target strength of squid IV. Measurements of the mean target strength of relatively large-sized live squid. Bull Fac Fish Hokkaido Univ 40:169-180

Cherel Y, Ridoux V (1992) Prey species and nutritive value of food fed during summer to King Penguin Aptenodytes patagonica chicks at rossession isiand, Crozei Aicinipelago. Ibis 134:118-127

Clarke MR (1986) A handbook for the identification of cephalopod beaks. Clarendon Press, Oxford
Clarke MR, Prince PA (1981) Cephalopod remains in the regurgitations of black-browed and grey-headed albatrosses at South Georgia. Br Antarct Surv Bull 54:1-7

Comiso JC, MCClain CR, Sullivan CW, Ryan JP, Leonard CL (1993) Coastal zone color scanner pigment concentrations in the Southern Ocean and relationships to geophysical surface features. J Geophys Res 98:2419-2451

Eastman JT (1993) Antarctic fish biology. Academic Press, San Diego

Elizarov AA, Grechina AS, Kotenev BN, Kuzetsov AN (1993) Peruvian jack mackerel, Trachurus symmetricis murphyi, in the open waters of the South Pacific. J Ichthyol 33: $86-103$

FAO Fishenes Department (1992) Marine fisheries and the law of the sea: a decade of change. Special chapter (revised) of the State of Food and Agriculture 1992. FAO Fisheries Circular No. 853. FAO, Rome

Filnn AA, Gorchinsky KV, Kiseleva VM (1990) Bromass of myctophids in the Atlantic sector of the Southern Ocean as estimated by acoustic surveys. SC-CCAMLR-SSP/7. $417-431$

Foote KG, Knudsen HP, Vestnes G, MacLennan DN, Simmonds EJ (1987) Calibration of acoustic instruments for fish density estimation: a practical guide. ICES Coop Res Rep 144:1-69

Gerasimova OV (1990) Feeding and food intake of Electrona carlsbergi (Tåning, 1932) Myctophidae. SC-CCAMLRSSP/7:411-416

Gordon AL, Georgi DT, Taylor HW (1977) Antarctic Polar Frontal Zone in the Western Scotia Sea-Summer 1975. J Phys Oceanogr 7:309-328

Harrison-Matthews L. (1929) The natural history of the elephant seal. Discovery Rep 1:235-255

Hindell MA (1988) The diet of the king penguin Aptenodytes patagonicus at Macquarie Island. Ibis 130:193-203

Le Fevre $J$ (1986) Aspects of the biology of frontal systems. Adv Mar Biol 23:163-299

Lipinski M (1979) Universal maturity scale for the commercially important squids. The results of maturity classification of the Illex illecebrosus population for the years 1973-77. ICNAF Research Document 79/2/38, Senal 5364

Olson DB, Hitchcock GL, Mariano AJ, Ashjian CJ, Peng G, Nero RW, Podesta GP (1994) Life on the edge: marine life and fronts. Oceanography 7:52-60

Piatkowski U, Rodhouse PG, White MG, Bone DG, Symon C (1994) Nekton community of the Scotia Sea as sampled by the RMT25 during austral summer. Mar Ecol Prog Ser 11:13-28

Prince PA (1980) The food and feeding ecology of greyheaded albatross Diomedea chrysostoma and blackbrowed albatross $D$. melanophrys. Ibis 122:476-488

Prince PA, Wood AG, Barton T, Croxall JP (1992) Satellite trackung of wandering albatrosses (Diomedea exulans) in the South Atlantic. Antarct Sci 4:31-36

Rodhouse PG (1989) Pelagic cephalopods caught by nets during the Antarctic research cruises of the Polarstern and Walther Herwig, 1984-87. Arch FischWiss 39:111-121

Rodhouse PG (1990) Cephalopod fauna of the Scotia Sea at South Georgia: potential for commercial exploitation and possible consequences. In: Kerry K. Hempel G (eds) Antarctic ecosystems. Ecological change and conservation. Springer, Berlin, p 289-298

ruchiouise $\mathrm{rG}$ (19९1) Population ctructure of Martialia hyadesi (Cephalopoda: Ommastrephidae) at the Antarctic Polar Front and the Patagonian Shelf. Bull Mar Sci 49:404-418 
Rodhouse PG, Arnbom TR, Fedak MA, Yeatman J, Murray AWA (1992a) Cephalopod prey of the southern elephant seal Mirounga leoniná L. Can J Zool 70:1007-1015

Rodhouse PG. Clarke MR, Murray AWA (1987) Cephalopod prey of the wandering albatross Diomedea exulans. Mar Biol 96:1-10

Rodhouse PG, Croxall JP. Prince PA (1993) Towards an assessment of the stock of the ommastrephid squid Martialia hyadesi in the Scotia Sea: data from predators. In Okutani T, O'Dor RK, Kubodera $T$ (eds) Recent advances in cephalopod fisheries biology. Tokai University Press Tokyo, p 433-440

Rodhouse PG, Hatfield EMC, Symon C (1992b) Early life cycle of cephalopods in relation to the major oceanographic features of the southwest Atlantic Ocean. Mar Ecol Prog Ser 89:183-195

Rodhouse PG, Piatkowski U (1995) Fine-scale distribution of juvenile cephalopods in the Scotia Sea and adaptive allometry of the brachial crown. Mar Biol 124:111-117

Rodhouse PG, Piatkowski U, Murphy EJ, White MG, Bone DG (1994a) Utility and limits of biomass spectra: the nekton community sampled with the RMT25 in the Scotia Sea during austral summer. Mar Ecol Prog Ser 112:29-39

Rodhouse PG, Prince PA (1993) Cephalopod prey of the black-browed albatross Diomedea melanophrys at South Georgia. Polar Biol 13:373-376

Rodhouse PG, Prince PA, Clarke MR, Murray AWA (1.990) Cephalopod prey of the grey-headed albatross Diomedea chrysostoma. Mar Biol 104:353-362

Rodhouse PG, Robinson K, Gajdatsy SB, Daly HI, Ashmore MJS (1994b) Growth, age structure and environmetal history in the cephalopod Martialia hyadesi (Teuthoidea: Ommastrephidael at the Antarctic Polar Frontal Zone and on the Patagonian Shelf edge. Antarct Sci 6 . $259-267$

This article was submitted to the editor
Rodhouse PG, White MG (1995) Cephalopods occupy the ecological niche of epipelagic fish at the Antarctic Polar Frontal Zone. Biol Bull 189:77-80

Rodhouse PG, White MG, Jones MRR (1992c) Trophic relations of the cephalopod Martialia hyadesi (Teuthoidea: Ommastrephidae) at the Antarctic Polar Front. Mar Biol 114:415-421

Rodhouse PG, Yeatman J (1990) Redescription of Martialia hyadesi Rochebrune and Mabille, 1889 (Mollusca: Cephalopoda). Bull Br Mus (Nat Hist), Zool 56:135-143

Sabourenkov EN (1990) Mesopelagic fish of the Southern Ocean-summary results of recent Soviet studies. SC-C.CAMLR-SSP/7:433-457

Simrad (1992) Simrad EK500 scientific echo sounder, P2170E edn. Simrad, Horten

Socha DG, Watkins JL, Brierley AS (1996) A visualizationbased post processing system for analysis of acoustic data. ICES J Mar Sci 53:335-338

Sugimoto T, Tameishi H (1992) Warm-core rings, streamers and their role on the fishing ground formation around Japan. Deep Sea Res 39(Suppl 1):S183-S201

Waring GT, Fairfield CP, Ruhsam CM, Sano M (1993) Sperm whales assoclated with Gulf Stream features off the northeastern USA shelf. Fish Oceanogr 2:101-105

Watkins JL, Brierley AS (1996) A post-processing technique to remove background noise from echo-integration data. ICES J Mar Sci 53:339-344

Wormuth JH, Roper CFE (1983) Quantitative sampling of oceanic cephalopods by nets: problems and recommendations. Biol Oceangr 2:357-377

Yatsu A (1995) Zoogeography of the epipelagic fishes in the South Pacific Ocean and the Pacific sector of the Subantarctic, with special reference to the ecological role of slender tuna, Allothunnus fallai. Bull Natl Res Inst Far Seas Fish 3:1-145

Manuscript first received: October 25, 1995

Revised version accepted: January 4, 1996 